\title{
The Effect of Debt to Asset Ratio and Debt to Equity Ratio on Return on Assets in Hotel, Restaurant, and Tourism Sub Sectors Listed on Indonesia Stock Exchange for the 2014-2018 Period
}

\author{
Ischak P Lumbantobing; Lod Sulivyo; Dede Nuary Sukmayuda; Anggi Dinia Riski \\ Sekolah Tinggi Ilmu Ekonomi PPI, Indonesia \\ http://dx.doi.org/10.18415/ijmmu.v7i9.1982
}

\begin{abstract}
This study aims to determine the effect of debt to asset ratio and debt to equity ratio on return on assets in hotel, restaurant and tourism sub-sectors listed on the Indonesia Stock Exchange for the 20142018 period, either partially or simultaneously. This research is a quantitative research. The sampling technique in this study was purposive sampling with a sample of 16 companies from a population of 35 sub-sector companies including hotel, restaurant and tourism listed on Indonesia Stock Exchange. The data analysis techniques used in this study included descriptive statistics, classic assumption tests, partial correlation analysis, coefficient of determination, multiple regression analysis, and hypothesis testing. Additionally, multiple regression equation in this study was ROA $=0.308+0.154 \mathrm{DAR}-0.038 \mathrm{DER}$. The results of this study indicated that debt to asset ratio partially had a positive and significant effect on return on assets. It was indicated by $\beta$ value of 0.154 and significance level of $0.000<0.05$. In addition, the results also found that debt to equity ratio had a negative effect on return on assets, in which $\beta$ value was- 0.038 and significance level of $0.000<0.05$. Debt to asset ratio and debt to equity ratio simultaneously have a significant effect on return on assets, indicated by a significance level of $0.000<0.05$.
\end{abstract}

Keywords: Debt to Asset Ratio; Debt to Equity Ratio; Return on Assets; Indonesia Stock Exchange

\section{Introduction}

One element that frequently becomes the concern of a company is profitability (Putriani, 2010). It is because the company always tries to get a high profit than the capital invested (Kotler et al., 2002). With a profit, the company can move and increase business activities. It also can continue to survive and thrive in the future (Chun et al., 2015). Therefore, the profitability ratio in this case is useful for knowing how profitable a company is (Pervan \& Višić, 2012).

Furthermore, tourism growth in Indonesia shows an increase every year. It can be seen from increasing number of tourist visits from 2014 to 2018. According to data from Central Statistics Agency (BPS) in 2014, the number of foreign tourist visits reached 9.44 million visits. It continues to increase until in 2018, the number of foreign tourist arrivals reached 15.81 million visits. Likewise, the number of domestic tourist trips in 2014 reached 251.24 million, and in 2018 reached 303.4 million. 
Central Statistics Agency (BPS) data also revealed that in 2018, the largest foreign tourists' expenditure was on accommodation and food and beverages, which respectively reached $31.32 \%$ and $18.39 \%$ of the total expenditure. It indicated that hotels and restaurants have a major contribution to tourism. Thus, both are required to continue growing by providing the best service to impress tourists.

The growth in hotel, restaurant and tourism sub-sectors is certainly expected to be accompanied by an increase in profitability. The average value of return on assets in hotel, restaurant and tourism subsector companies shows fluctuation during the 2014-2018 period. In 2014, the average return on assets was $3.30 \%$, then decreased in 2015 to $2.30 \%$. In 2016, the average return on assets increased to $2.60 \%$ and increased again in 2017 to $3.51 \%$.In addition,in 2018, the average return on assets decreased to $2.89 \%$.

Moreover, the average value of debt to asset ratio in hotel, restaurant, and tourism sub-sector companies has fluctuated during the 2014-2018 period. In 2014 to 2015, the average debt to asset ratio increased from $40.98 \%$ to $41.57 \%$. It was not in line with the decreasing average return on assets in the same year. In 2016, the average value of debt to asset ratio increased to $43.28 \%$, in line with the average value of return on assets that increased in the same year. In 2017, the average debt to asset ratio value decreased to $43.16 \%$, which was not in line with the average value of return on assets which increased in the same year. In 2018, the average debt to asset ratio value decreased to $41.91 \%$, in line with the decrease in the average value of return on assets in the same year. The graph of the average debt to equity ratio is explained as follows.

More importantly, the average value of debt to equity ratio in hotel, restaurant, and tourism subsector companies has fluctuated during the 2014-2018 period. In 2014 and 2015, the average debt to equity ratio increased from $95.65 \%$ to $104.48 \%$. It was not in line with the decreasing average return on assets in the same year. In 2016, the average debt to equity ratio increased again to $107.87 \%$, in line with the average value of return on assets that increased in the same year. In 2017, the average value of debt to equity ratio decreased to $97.95 \%$, which was not in line with the average value of return on assets that increased in the same year. In 2018 , the average debt to equity ratio value decreased to $94.66 \%$, in line with the decrease in the average value of return on assets in the same year.

Additionally, during the 2014-2018 period, the increase or decrease in the average value of debt to asset ratio and the average value of debt to equity ratio in hotel, restaurant, and tourism sub-sector companies sometimes showed the same direction or not the same direction with the increase or decrease in the average value of return on assets. Therefore, the researchers intended to conduct a research on the effect of the debt to asset ratio and debt to equity ratio on return on assets of hotel, restaurant, and tourism sub-sector companies.

\section{Framework}

This research examined: debt to asset ratio variable, debt to equity ratio variable, and return on assets variable. Based on these research variables, the research framework is described as follows:

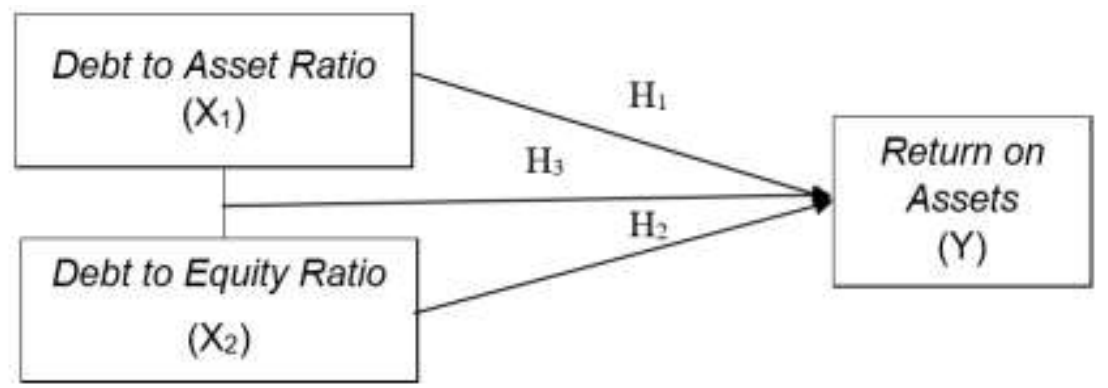

Figure 1. Framework 
Note:

$\mathrm{H}_{1}$ : The effect of debt to asset ratio on return on assets.

$\mathrm{H}_{2}$ : The effect of debt to equity ratio on return on assets.

$\mathrm{H}_{3}$ : The effect of debt to asset ratio and debt to equity ratio on return on assets.

\section{Research Methodology}

\section{Type of Research}

This research is a quantitative research. According to Sugiyono (2014) "Quantitative research methods can be interpreted as research methods based on positivism philosophy; is used to research on a particular population or sample; the sampling technique is generally done randomly; data collection utilizes research instruments; uses quantitative/statistical data analysis with the aim of testing the predetermined hypothesis ".

\section{Type and Source of Data}

The type of data used in this study is quantitative data or data in the form of numbers, in the form of annual financial statements of the hotel, restaurant, and tourism sub-sector companies published in the 2014-2018 period. The data source used in this research is secondary data. According to Sugiyono (2014) "Secondary sources are sources that do not directly provide data to data collectors, for example through other people or through documents". In this study, data were obtained from Indonesia Stock Exchange and the sample company websites.

\section{Data Collection Method}

Sugiyono (2014) strongly advocated that "Data collection method is the most important step in a research since the main purpose of research is to get data. Researchers will not get data that fulfill applicable data standards without knowing data collection method. This study utilized two data collection methods: documentation and literature study.

\section{Population and Sample}

The population of this study were all sub-sector companies including hotel, restaurant, and tourism listed on Indonesia Stock Exchange for the 2014-2018 period with a total of 35 companies. Sampling was conducted using a non-probability sampling technique. The following are the criteria for hotel, restaurant and tourism sub-sector companies determined to select the sample:

1. Hotel, restaurant and tourism sub-sector companies listed on Indonesia Stock Exchange for the 20142018 period.

2. Hotel, restaurant and tourism sub-sector companies that published complete and consistent financial reports for the 2014-2018 period.

Based on these criteria, there were 16 companies selected with 5 years of financial reports for the 2014-2018 period, so that there were 80 financial reports. The following is a list of selected hotel, restaurant, and tourism sub-sector companies: 
Table 1. List of Sample Companies

\begin{tabular}{|c|c|c|}
\hline No & Code & Company Name \\
\hline 1 & ARTA & PT. Arthavest Tbk \\
\hline 2 & BAYU & PT. Bayu Buana Tbk \\
\hline 3 & FAST & PT. Fast Food Indonesia Tbk \\
\hline 4 & GMCW & PT. Grahamas Citrawisata Tbk \\
\hline 5 & ICON & PT. Island Concepts Indonesia Tbk \\
\hline 6 & INPP & PT. Indonesian Paradise Property Tbk \\
\hline 7 & JIHD & PT. Jakarta International Hotels and Development Tbk \\
\hline 8 & JSPT & PT. Jakarta Setiabudi Internasional Tbk \\
\hline 9 & MAMI & PT. Mas Murni Indonesia Tbk \\
\hline 10 & PANR & PT. Panorama Sentrawisata Tbk \\
\hline 11 & PDES & PT. Destinasi Tirta Nusantara Tbk \\
\hline 12 & PGLI & PT. Pembangunan Graha Lestari Tbk \\
\hline 13 & PJAA & PT. Pudjiadi \& Sons Tbk \\
\hline 14 & PNSE & PT. Pioneerindo Gourmet International Tbk \\
\hline 15 & PTSP & PT. Pudjiadi Prestige Tbk \\
\hline 16 & PUDP &
\end{tabular}

\section{Research Variable}

\section{Dependent Variable}

According to Sugiyono (2018:61), "The dependent variable is the variable that is affected or which becomes the result because of the independent variable". The dependent variable in this study was return on assets. The formula for finding return on assets is as follows:

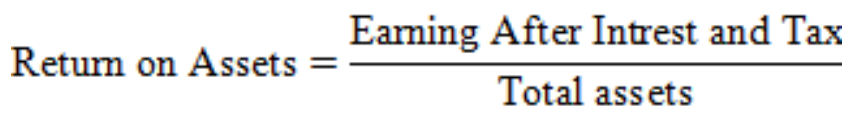

2. Independent Variable

According to Sugiyono (2018:61), "The independent variable is a variable that affects or causes the change or the emergence of the dependent variable". The independent variable in this study is debt to asset ratio and debt to equity ratio.

a. Debt to asset ratio

The formula for finding a debt to asset ratio is as follows:

$$
\text { Debt to Asset Ratio }=\frac{\text { Total debt }}{\text { Total assets }}
$$

b. Debt to Equity Ratio

The formula for finding debt to equity ratio is as follows:

$$
\text { Debt to Equity Ratio }=\frac{\text { Total debt }}{\text { Equity }}
$$




\section{Data Analysis Technique}

The data analysis techniques used in this research included descriptive statistics, classical assumption test, partial correlation analysis, coefficient of determination, multiple regression analysis, and hypothesis testing with the help of SPSS 23 program.

\section{Research Result}

\section{Classical Assumption Test}

\section{a. Normality Test}

Ghozali (2016) claimed that "Normality test aims to test whether in the regression model, confounding or residual variables have a normal distribution". Normality test in this study was carried out using Kolmogorov-Smirnov non-parametric statistical analysis. Following are the results of normality test:

Table 2. Normality Test Results

One-Sample Kolmogorov-Smirnov Test

\begin{tabular}{|ll|r|}
\hline $\mathrm{N}$ & & Unstandardized Residual \\
Normal Parameters ${ }^{\mathrm{a}, \mathrm{b}}$ & Mean & 80 \\
& Std. Deviation & .0000000 \\
Most Extreme Differences & Absolute & 2.51840211 \\
& Positive & .048 \\
& Negative & .048 \\
Test Statistic & & -.040 \\
Asymp. Sig. (2-tailed) & & .048 \\
\hline
\end{tabular}

a. Test distribution is Normal.

b. Calculated from data.

c. Lilliefors Significance Correction.

d. This is a lower bound of the true significance.

Based on table 2 , the significance level is 0.200 which is above 0.05 . It means that the residual data was normally distributed.

b. Multicollinearity Test

Ghozali (2016) stated that "Multicollinearity test aims to test whether there is a correlation between independent variables (independent) in the regression model". It can be seen from tolerance and VIF values. Following are the multicollinearity test results:

Table 3. Multicollinearity Test Results

\section{Coefficients $^{\mathrm{a}}$}

\begin{tabular}{|ll|r|r|}
\hline \multirow{2}{*}{ Model } & \multicolumn{2}{|c|}{ Collinearity Statistics } \\
\cline { 3 - 4 } & Tolerance & \multicolumn{2}{|c|}{ VIF } \\
\hline & Debt to Asset Ratio & .218 & 4.590 \\
& Debt to Equity Ratio & .218 & 4.590 \\
\hline
\end{tabular}

a. Dependent Variable: Return on Assets 
Based on table 4.5, none of the independent variables have a tolerance value less than 0.10 $(0.218>0.10)$ and none have a VIF value of more than $10(4.590<10)$. It indicates that there was no multicollinearity.

\section{c. Heteroscedasticity Test}

Ghozali (2016) claimed that "Heteroscedasticity test aims to test whether there is a variance from the residuals of one observation to another in the regression model. The heteroscedasticity test in this study was carried out by looking at the scatterplot graph. The following is a scatterplot graph of the results of the heteroscedasticity test:

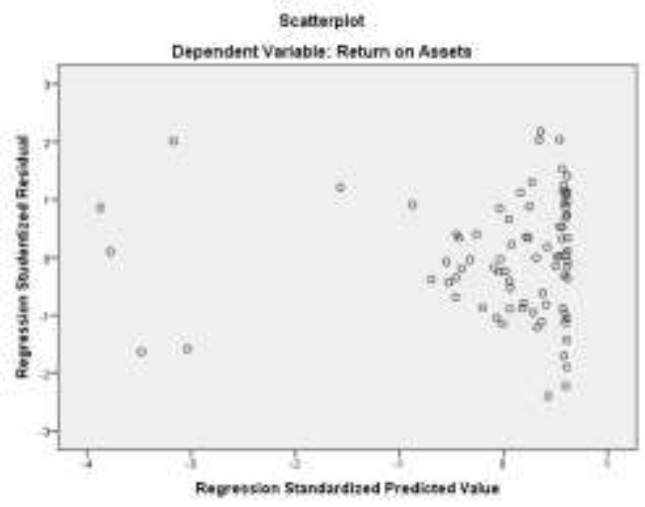

Figure 2. Heteroscedasticity Test Results

Based on Figure 2, the dots spread randomly either above or below the number 0 on the $\mathrm{Y}$ axis. It indicates that there was no heteroscedasticity.

\section{d. Autocorrelation Test}

According to Ghozali (2016), "Autocorrelation test aims to test whether in the linear regression model there is a correlation between confounding error in period $t$ and confounding error in period t-1 (previous)". The autocorrelation test in this study was carried out using Durbin-Watson test. Here are the results of Durbin-Watson test:

Table 4. Autocorrelation Test Results Model Summary ${ }^{\mathrm{b}}$

\begin{tabular}{|l|c|}
\hline Model & Durbin-Watson \\
\hline 1 & 1.748 \\
\hline
\end{tabular}

a. Predictors: (Constant), Debt to Equity Ratio, Debt to Asset Ratio

b. Dependent Variable: Return on Assets

Based on table 4.6, Durbin-Watson value is 1.748. The value of Durbin-Watson table with the number of independent variables $(\mathrm{k})$ is 2 and the number of samples $(\mathrm{n})$ is 80 , obtaining a value of du $=$ 1.688 and a value of $\mathrm{dl}=1.586$. Thus, $\mathrm{du}<\mathrm{dw}<4-\mathrm{du}(1.688<1.748<2.312)$. It means that there is no autocorrelation. 


\section{Partial Correlation Analysis}

Partial correlation analysis aims to determine the level of relationship between independent variable and dependent variable. The correlation coefficient can be seen from Pearson correlation value. Following are the results of partial correlation analysis:

Table 5. Partial Correlation Analysis Correlations

\begin{tabular}{|ll|r|r|r|}
\hline & & $\begin{array}{c}\text { Debt to Asset } \\
\text { Ratio }\end{array}$ & $\begin{array}{c}\text { Debt to Equity } \\
\text { Ratio }\end{array}$ & \multicolumn{1}{c|}{$\begin{array}{c}\text { Return on } \\
\text { Assets }\end{array}$} \\
\hline Debt to Asset Ratio & Pearson Correlation & 1 & $.884^{* *}$ & $-.237^{*}$ \\
& Sig. (2-tailed) & & .000 & .034 \\
& $\mathrm{~N}$ & 80 & 80 & 80 \\
\hline Debt to Equity Ratio & Pearson Correlation & $.884^{* *}$ & 1 & $-.476^{* *}$ \\
& Sig. (2-tailed) & .000 & & .000 \\
& $\mathrm{~N}$ & 80 & 80 & 80 \\
\hline Return on Assets & Pearson Correlation & $-.237^{*}$ & $-.476^{* *}$ & 1 \\
& Sig. (2-tailed) & .034 & .000 & 80 \\
& $\mathrm{~N}$ & 80 & & 80 \\
\hline
\end{tabular}

**. Correlation is significant at the 0.01 level (2-tailed).

*. Correlation is significant at the 0.05 level (2-tailed).

Based on table 5, the value of Pearson correlation of debt to asset ratio to return on assets is -0.237 . It shows a negative relationship and a correlation value of 0.237 , meaning that debt to asset ratio has a low level of relationship to return on assets. Additionally, the value of Pearson correlation of debt to equity ratio to return on assets is -0.476 . It shows a negative relationship and a correlation value of 0.476 , meaning that debt to equity ratio has a moderate level of relationship to return on assets.

\section{Coefficient of Determination}

Ghozali (2016) stated that "Coefficient of determination basically measures how far the model's ability to explain the variation in the dependent variable". It can be seen from the $\mathrm{R}$ square value. The following is the coefficient of determination in this study:

Table 6. Coefficient of Determination Model Summary ${ }^{b}$

\begin{tabular}{|l|r|r|r|r|}
\hline Model & $\mathrm{R}$ & \multicolumn{1}{c|}{ R Square } & Adjusted R Square & \multicolumn{1}{c|}{$\begin{array}{c}\text { Std. Error of the } \\
\text { Estimate }\end{array}$} \\
\hline 1 & $.618^{\mathrm{a}}$ & .382 & .366 & 2.55090 \\
\hline
\end{tabular}

a. Predictors: (Constant), Debt to Equity Ratio, Debt to Asset Ratio

b. Dependent Variable: Return on Assets

Based on table 6 , the $\mathrm{R}$ square value is 0.382 or $38.2 \%$. It indicates that the variation in return on assets variable which can be explained by debt to asset ratio variable and debt to equity ratio variable is $38.2 \%$. The remaining $61.8 \%(100 \%-38.2 \%)$ is explained by other variables. 


\section{Multiple Regression Analysis}

According to Sugiyono (2014), "Multiple regression analysis is used by researchers who intend to predict how the state (fluctuation) of the dependent variable (criterion) when two or more independent variables as predictor factors are manipulated". Here are the results of multiple regression analysis:

Table 7. Multiple Regression Analysis Coefficients $^{\mathbf{a}}$

\begin{tabular}{|c|c|c|c|c|}
\hline \multirow{2}{*}{\multicolumn{2}{|c|}{ Model }} & \multicolumn{2}{|c|}{ Unstandardized Coefficients } & \multirow{2}{*}{$\begin{array}{c}\begin{array}{c}\text { Standardized } \\
\text { Coefficients }\end{array} \\
\text { Beta }\end{array}$} \\
\hline & & $\mathrm{B}$ & Std. Error & \\
\hline & (Constant) & .308 & 1.033 & \\
\hline & Debt to Asset Ratio & .154 & .035 & .845 \\
\hline & Debt to Equity Ratio & -.038 & .006 & -1.223 \\
\hline
\end{tabular}

a. Dependent Variable: Return on Assets

Based on table 7, the following regression equation is obtained:

$$
\mathrm{ROA}=0.308+0.154 \mathrm{DAR}-0.038 \mathrm{DER}
$$

a. The constant coefficient value is 0.308 , which shows that if debt to asset ratio and debt to equity ratio have a value of 0 , then return on assets value is $0.308 \%$.

b. The coefficient value of debt to asset ratio is 0.154 , which indicates that debt to asset ratio has a positive relationship with return on assets. It means that if debt to asset ratio increases by $1 \%$, then return on assets will increase by $0.154 \%$, assuming that debt to equity ratio variable is stable.

c. The coefficient value of debt to equity ratio is -0.038 , which indicates that debt to equity ratio has a negative relationship with return on assets. It means that if debt to equity ratio increases by $1 \%$, return on assets will decrease by $0.038 \%$, assuming that debt to asset ratio variable is stable.

\section{Hypothesis Testing}

\section{T-Test}

According to Ghozali (2016), "Basically, t-test shows how far the influence of one explanatory/independent variable individually in explaining the variation of the dependent variable". The following are the results of t-test in this study:

Table 8. Results of t-test

Coefficients $^{\mathrm{a}}$

\begin{tabular}{|c|c|c|c|c|c|c|}
\hline \multirow{2}{*}{\multicolumn{2}{|c|}{ Model }} & \multicolumn{2}{|c|}{ Unstandardized Coefficients } & $\begin{array}{c}\text { Standardized } \\
\text { Coefficients }\end{array}$ & \multirow[b]{2}{*}{$\mathrm{t}$} & \multirow[b]{2}{*}{ Sig. } \\
\hline & & $\mathrm{B}$ & Std. Error & Beta & & \\
\hline \multirow[t]{3}{*}{1} & (Constant) & .308 & 1.033 & & .298 & .767 \\
\hline & Debt to Asset Ratio & .154 & .035 & .845 & 4.402 & .000 \\
\hline & Debt to Equity Ratio & -.038 & .006 & -1.223 & -6.376 & .000 \\
\hline
\end{tabular}

a. Dependent Variable: Return on Assets 
Based on table 8 , the results of the t-test can be concluded as follows:

a. The $t_{\text {count }}$ value of debt to asset ratio variable is 4.402 with a significance level of 0.000 . The significance level less than 0.05 indicates that debt to asset ratio variable partially has a significant effect on return on assets variable.

b. The $t_{\text {count }}$ value of debt to equity ratio variable is -6.376 with a significance level of 0.000 . The significance level less than 0.05 indicates that debt to equity ratio variable partially has a significant effect on the return on assets variable.

\section{F-test}

According to Ghozali (2016), "The F-test tests the joint hypothesis that b1, b2, and b3 are equal to zero simultaneously". The following are the results of the F-test:

Table 8. Results of F-test

ANOVA ${ }^{a}$

\begin{tabular}{|ll|r|r|r|r|r|}
\hline Model & & Sum of Squares & Df & Mean Square & F & Sig. \\
\hline 1 & Regression & 310.217 & 2 & 155.108 & 23.837 & $.000^{\mathrm{b}}$ \\
& Residual & 501.046 & 77 & 6.507 & & \\
& Total & 811.262 & 79 & & & \\
\hline
\end{tabular}

a. Dependent Variable: Return on Assets

b. Predictors: (Constant), Debt to Equity Ratio, Debt to Asset Ratio

Based on table 8, the results of the $\mathrm{F}$ test show $\mathrm{F}_{\text {count }}$ value of 23.837 with a significance level of 0.000. The significance level less than 0.05 indicates that debt to asset ratio variable and debt to equity ratio variable simultaneously have a significant effect on return on assets variable.

\section{Discussion}

\section{The Effect of Debt to Asset Ratio on Return on Assets}

Based on results of t-test, debt to asset ratio had a significance level smaller than $0.05(0.000$ $<0.05)$, meaning that debt to asset ratio partially had a significant effect on return on assets. Furthermore, results of multiple regression analysis showed that debt to asset ratio had a $\beta$ value of 0.154 . It means that debt to asset ratio had a positive effect on return on assets. Thus, it could be concluded that debt to asset ratio partially had a positive and significant effect on return on assets $\left(\mathrm{H}_{0}\right.$ was accepted and $\mathrm{H}_{a}$ was rejected).

The results of this study indicated that debt to asset ratio had a positive effect or was directly proportional to return on assets. It means that any increase in debt to asset ratio would have an impact on the increase in return on assets. This is because hotel, restaurant and tourism sub-sector companies in this study during the 2014-2018 period had a smaller amount of debt compared to their total assets. The average debt to asset ratio in this study was $42.18 \%$, indicating that only a few assets owned by the company were financed by debt so that the company's total assets could provide profit.

The results of this study are in accordance with the research results of Arif (2015) as well as Barus (2016) which claimed that debt to asset ratio has a positive and significant effect on return on assets. However, the results of this study are different from the research results conducted by Februansyah \& 
Yanuarti (2017) as well as Gunde et al., (2017) which found that debt to asset ratio has a negative and significant effect on return on assets.

\section{The Effect of Debt to Equity Ratio on Return on Assets}

Based on the t-test results, debt to equity ratio had a significance level smaller than $0.05(0.000$ $<0.05)$. It means that debt to equity ratio partially had a significant effect on return on assets. Moreover, the results of multiple regression analysis showed that debt to equity ratio had a $\beta$ value of -0.038 , meaning that debt to equity ratio had a negative effect on return on assets. Therefore, it could be concluded that debt to equity ratio partially had a negative and significant effect on return on assets $\left(\mathrm{H}_{0}\right.$ was rejected and $\mathrm{H}_{\mathrm{a}}$ was accepted).

The results of this study indicated that debt to equity ratio had a negative effect or was inversely related to return on assets. It means that any increase in debt to equity ratio would have an impact on lower returns on assets. This is because several sub-sector companies in this study during the 2014-2018 period had a larger amount of debt than their total capital. The average debt to equity ratio in this study was $100.49 \%$, indicating that corporate funding sources were more dominated by debt than equity. The amount of this debt to equity ratio can result in a greater risk of the company being burdened to pay off its debts to parties outside the company. The worst possibility is that it can result in less profit or even loss.

The results of this study are consistent with the results of research by Arif (2015) and Barus (2016) which concluded that debt to equity ratio has a negative and significant effect on return on assets. However, the results of this study are different from research results by Gunde et al., (2017) which found that debt to equity ratio has a positive and significant effect on return on assets.

\section{The Effect of Debt to Asset Ratio and Debt to Equity Ratio on Return on Assets}

Based on the results of the F-test, debt to asset ratio and debt to equity ratio had a significance level smaller than $0.05(0.000<0.05)$. Thus, it could be concluded that debt to asset ratio and the debt to equity ratio simultaneously had a significant effect on return on assets $\left(\mathrm{H}_{0}\right.$ was rejected and $\mathrm{H}_{\mathrm{a}}$ was accepted).

The results of this study indicate that debt to asset ratio and debt to equity ratio can influence the fluctuation of return on assets simultaneously. This is because the company will not be separated from outside funding, debt, to meet its capital needs. However, debt that has been obtained, regardless of the size, must be utilized properly so that it has an impact on high income and the profit earned is increased. If the company cannot manage its debt properly, the burden of paying loan principal along with interest will increase and reduce the amount of profit it gets, which makes it difficult for the company to pay off its debt. In this case, a company is at risk of bankruptcy if the amount of debt is greater and cannot be covered by the assets and capital it owns.

The results of this study are in accordance with research results conducted by Barus (2016) which stated that debt to asset ratio and debt to equity ratio have a significant effect on return on investment (return on assets). However, the results of this study are different from research results by Gunde et al., (2017) which found that debt to asset ratio and debt to equity ratio have no significant effect on return on assets.

\section{Conclusion}

Debt to asset ratio has a positive and significant effect on return on assets in hotel, restaurant and tourism sub-sector companies for the 2014-2018 period. This is based on the results of multiple regression analysis that debt to asset ratio has a $\beta$ value of 0.154 . Importantly, based on the results of t- 
test, debt to asset ratio has a significance level smaller than $0.05(0.000<0.05)$. Debt to equity ratio has a negative and significant effect on return on assets in hotel, restaurant and tourism sub-sector companies for the 2014-2018 period. This is based on the results of multiple regression analysis which states that debt to equity ratio has a $\beta$ value of -0.038 . In addition, $t$-test results indicate that debt to equity ratio has a significance level that is smaller than $0.05(0.000<0.05)$. Debt to asset ratio and debt to equity ratio simultaneously have a significant effect on return on assets in hotel, restaurant and tourism sub-sector companies for the 2014-2018 period. It is based on the results of F-test; debt to asset ratio and debt to equity ratio have a significance value smaller than $0.05(0.000<0.05)$.

\section{Reference}

Arif, S. (2015). Pengaruh Perputaran Modal Kerja, Leverage Dan Pertumbuhan Penjualan Terhadap Profitabilitas (Studi Pada Perusahaan Makanan Dan Minuman Yang Terdaftar Di Bursa Efek Indonesia Pada Tahun 2011-2013). Jurnal Administrasi Bisnis, 27(1).

Barus, I. S. L. (2016). Pengaruh Debt Ratio Dan Debt to Equity Ratio Terhadap Return on Investment (Studi Kasus Perusahaan Manufaktur di Bursa Efek Indonesia untuk Periode 2012).

Chun, S.-H., Hwang, H. J., \& Byun, Y.-H. (2015). Supply Chain Process and Green Business Activities: Application to Small and Medium Enterprises. Procedia-Social and Behavioral Sciences, 186, 862-867.

Februansyah, R., \& Yanuarti, I. (2017). Pengaruh financial leverage terhadap financial performance pada sektor industri manufaktur yang terdaftar di Bursa Efek Indonesia (BEI) Periode 2015. Ultima Management: Jurnal Ilmu Manajemen, 9(2), 33-48.

Ghozali, I. (2016). Aplikasi Analisis Multivariate dengan Program IBM SPSS 23 Edisi 8. Badan Penerbit Undip.

Gunde, Y. M., Murni, S., \& Rogi, M. H. (2017). Analisis Pengaruh Leverage Terhadap Profitabilitas Pada Perusahaan Manufaktur Sub Industri Food and Beverages Yang Terdaftar di BEI (Periode 20122015). Jurnal EMBA: Jurnal Riset Ekonomi, Manajemen, Bisnis Dan Akuntansi, 5(3).

Kotler, P., Jain, D. C., Jain, D., \& Maesincee, S. (2002). Marketing moves: A new approach to profits, growth, and renewal. Harvard Business Press.

Pervan, M., \& Višić, J. (2012). Influence of firm size on its business success. Croatian Operational Research Review, 3(1), 213-223.

Putriani, F. D. (2010). Pengaruh Struktur Kepemilikan, Tingkat Keuntungan Perusahaan, Risiko Perusahaan Terhadap Kinerja Intellectual Capital. Jurnal Akuntansi \& Auditing, 3(1), 45-65.

Sugiyono. (2014). Metode Penelitian Kuantitatif, Kualitatif, Dan R\&D. CV Alfabeta.

\section{Copyrights}

Copyright for this article is retained by the author(s), with first publication rights granted to the journal.

This is an open-access article distributed under the terms and conditions of the Creative Commons Attribution license (http://creativecommons.org/licenses/by/4.0/). 